\title{
Effects of pH on filtration of freshwater pearl mussel Lamellidens marginalis, Lamarck (Bivalvia: Unionidae) under laboratory conditions
}

\author{
SHAFIQUL ISLAM, MD. TAUHID HASAN, MOHAMMAD FERDOUS SIDDIQUE, \\ MOHAMMAD MONIRUZZAMAN ${ }^{1}$, MD. SAZZAD HOSSAIN ${ }^{2}$ AND M. JASIM UDDIN* \\ Department of Fisheries Management, Bangladesh Agricultural University, Mymensingh 2202, Bangladesh \\ ${ }^{1}$ Bangladesh Fisheries Research Institute, Mymensingh 2201, Bangladesh \\ ${ }^{2}$ Department of Aquaculture, Bangladesh Agricultural University, Mymensingh2202, Bangladesh \\ "Email: jasimfm@bau.edu.bd
}

\begin{abstract}
The study was conducted to evaluate the effects of $\mathrm{pH}$ on the filtration rate of freshwater pearl mussel Lamellidens marginalis under laboratory conditions. Three treatments were used in triplicate; treatment $1\left(\mathrm{~T}_{1}\right)$ at $\mathrm{pH} 7.5$, treatment $2\left(\mathrm{~T}_{2}\right)$ at $\mathrm{pH} 8.0$ and treatment $3\left(\mathrm{~T}_{3}\right)$ at $\mathrm{pH} 8.5$. Ten mussels were stocked in each aquarium with continuous aeration. After 48 hours, $40 \mathrm{ml}$ eutrophicated water having $34.75 \mathrm{x}$ $10^{5}$ to $36.0 \times 10^{5}$ cells $/ \mathrm{ml}$ of phytoplankton were provided in each aquarium. Initial concentration of phytoplankton was $14400 \pm 360.55,13900 \pm 360.55$ and $14133 \pm 404.14$ cells $/ \mathrm{ml}$, whereas the final concentrations were $10300 \pm 100.00,8300 \pm 200.00$ and $10333 \pm 57.73$ cells $/ \mathrm{ml}$ in $\mathrm{T}_{1}, \mathrm{~T}_{2}$ and $\mathrm{T}_{3}$, respectively. The reduction rate was consistently lower in $\mathrm{T}_{2}$ when compared to other treatments. Mussels of $\mathrm{T}_{2}(\mathrm{pH} \mathrm{8.0)}$ exhibited significantly higher filtration rate $(p<0.05)$ over $\mathrm{T}_{1}(\mathrm{pH} 7.5)$ and $\mathrm{T}_{3}(\mathrm{pH} 8.5)$ at all sampling times. The minimum filtration rate $58.03 \pm 32.79 \mathrm{ml} / \mathrm{mussel} / \mathrm{h}$ was found in $\mathrm{T}_{3}$ after $1 \mathrm{~h}$ exposure, whereas the highest filtration rate $110.94 \pm 21.68 \mathrm{ml} / \mathrm{mussel} / \mathrm{h}$ was obtained in $\mathrm{T}_{2}$ after $2 \mathrm{~h}$ exposure. The results concluded that the $\mathrm{pH}$ has a clear effect on feeding habit of freshwater pearl mussel and $\mathrm{pH} 8$ provides environment friendly to maximize the filtration of $L$. marginalis.
\end{abstract}

Keywords: Lamellidens marginalis, pH, Phytoplankton, Unionidae

\section{Introduction}

Bivalves remove particulate organic matter (POM) and suspended algae from the water column. Mussels process large volumes of water and exposed to dissolved toxic substances such as heavy metals (Jana and Das 1997, Kadar et al. 2002). On other hand, mussels are efficient filter feeders and can siphon nutrients from water column by means of depleting phytoplankton (Soto and Mena 1999, Areekijseree et al. 2004). They act as natural water cleaner and bioindicators of water body which would help to maintain the river and stream ecosystem (Areekijseree et al. 2004, Dan et al. 2001). Freshwater mussels are the most important components of food webs which linked to multiple trophic levels (Nobles and Zhang 2015). Furthermore, freshwater mussels are declining from the ecosystem due to water pollution, reduction of fish hosts as well as indiscriminate harvesting of mussels from natural habitat for commercial purposes. Nowadays, freshwater mussels have great interest in laboratory-based propagation and rearing techniques to better understand their ecological and eco-toxicological effects (Patterson et al. 2018). However, most important challenges in freshwater mussel culture are maintaining phytoplankton levels and stable water qualities in culture environment (Kunz et al. 2020). 
Filtration rate is a fundamental parameter in bio-energetic studies of suspension feeding of bivalves community. A vast number of methods and measurements of bivalve filtration rates in relation to factors such as ambient algal concentration and temperature were carried out since the beginning of the 21st century (Soucek et al. 2001). Bivalve molluscs can utilize their calcium carbonate $\left(\mathrm{CaCO}_{3}\right)$ reserves to buffer the impairments in haemolymph pH (Heming et al. 1988). It was reported that the higher temperature with alkaline $\mathrm{pH}$ of water can increase the filtration rate in freshwater mussels than the lower temperature with lower or acidic pH (Loayza-Muro and Elias-Letts 2007). Temperature and body size of mussels were also affected on the filtration rate (Pestana et al. 2009). Bivalves filter water continuously and feed on plankton (Mandal et al. 2007). Bivalves, particularly mussels, are efficient filter feeders that are capable of depleting the water column of phytoplankton (Dame et al. 1991).

There are two species of pearl producing bivalves are available in Bangladesh such as Lamellidens marginalis and $L$. corrianus, of which $L$. marginalis is the most preferred freshwater bivalve species that are used as food by some ethnic groups in Bangladesh, India and Nepal (Dan et al. 2001). In Bangladesh, L. marginalis are collected only from natural sources like rivers, ponds, etc. and are predominantly used for the production of lime $\left(\mathrm{CaCO}_{3}\right)$, and for poultry and aquaculture feeds (Siddique et al. 2020). The L. marginalis is an important pink pearl producing freshwater mussel having an increasing demand in pearl producing countries (Miah et al. 2000). Environmental factors such as, temperature, salinity, DO, pH, alkalinity etc. are playing vital roles in growth, survival, respiration, feeding and reproduction of bivalves (Uddin et al. 2013, Niogee et al. 2019, Siddique et al. 2020). Temperature and $\mathrm{pH}$ are most important factors that may effect on the physiology of freshwater mussels (Areekijseree et al. 2004, Sangsawang et al. 2019). The $\mathrm{pH}$ may impact on the physiology of L. marginalis by changing extracellular acid-base balance, metabolic activities and feeding behavior (Heming et al. 1988). In this study, the effects of $\mathrm{pH}$ on filtration rate of freshwater pearl mussel was found suitable because filtration rate is considered as an adequate sensitive sublethal endpoint for evaluating the biological effects of stress parameters like $\mathrm{pH}$ (Loayza-Muro and Elias-Letts 2007). Based on the above point of view, the present study was conducted to establish the effects of different levels of $\mathrm{pH}$ on filtration rate of freshwater pearl mussels L. marginalis under laboratory conditions.

\section{Materials and Methods}

Collection and maintenance of L. marginalis: The study was conducted in the Aquatic Ecology Laboratory of the Faculty of Fisheries, Bangladesh Agricultural University, Mymensingh. Adult freshwater pearl mussels L. marginalis were collected from a perennial pond by hand-picking. Mussels were transported to the laboratory using buckets with respective pond water that were continuously agitated. The experimental mussels were acclimated in fiberglass tanks (100-L capacity) for one week in dechlorinated and filtered tap water. Continuous aeration was provided in the tanks up to near saturation. Mussels having similar shell length ranged from 65 to $70 \mathrm{~mm}$ were selected for the experiment to avoid size-specific effects. The shell length, shell height and shell width were measured by using digital calipers in $\mathrm{mm}$ and recorded. 
Experimental design and data collection: For evaluating the effects of $\mathrm{pH}$ on filtration rate of L. marginalis, three treatments were designed in triplicate; treatment $1\left(\mathrm{~T}_{1}\right)-\mathrm{pH} 7.5$, treatment 2- $\mathrm{pH} 8.0$ and treatment $3-\mathrm{pH} 8.5$ in nine aquaria $(30 \mathrm{~cm} \times 30 \mathrm{~cm} \times 30 \mathrm{~cm})$. Sulfuric acid $\left(\mathrm{H}_{2} \mathrm{SO}_{4}\right)$ or sodium hydroxide $(\mathrm{NaOH})$ were added for maintaining constant $\mathrm{pH}$ of the aquaria throughout the experimental period. The $\mathrm{pH}$ range of this experiment was selected based on Loayza-Muro and Elias-Letts (2007) method. Each aquarium contained $10 \mathrm{~L}$ of dechlorinated and filtered tap water with no planktonic particles. Ten mussels were stocked in each aquarium with continuous gentle aeration. No planktonic food was provided for first 48 hours in all the treatments to deplete the gastric planktonic contents. After 48 hours, $40 \mathrm{ml}$ eutrophicated water having $34.75 \times 10^{5}$ to $36.0 \times 10^{5}$ cells $/ \mathrm{ml}$ of phytoplankton were provided in each aquarium. Water samples were collected at $0,1,2,3,4$ and $5 \mathrm{~h}$ after addition of planktonic algae and cell concentrations were counted by using S-R cell under a microscope (Binocular microscope, Olympus, Model B-2, Japan) and expressed as cells $/ \mathrm{ml}$.

The filtration rate (FR) was obtained via the indirect method of measuring the decrease in algal concentrations in the aquarium using the following formula of Coughlan (1969):

$$
\mathrm{FR}=(\mathrm{V} / \mathrm{nt}) \ln \left(\mathrm{C}_{0} / \mathrm{C}_{\mathrm{t}}\right)
$$

Where, $\boldsymbol{V}$ indicates volume of water per aquarium $(\mathrm{ml})=10000 \mathrm{ml}, \boldsymbol{n}$ is the number of individuals per aquarium $=10, \boldsymbol{t}$ denotes time (hour), $\boldsymbol{I n}$ is $\log$ base $e, \boldsymbol{C}$ and $\boldsymbol{C}_{\boldsymbol{t}}$ are algal concentrations (cells $/ \mathrm{ml})$ at time 0 and at time t (h), respectively. Water quality parameters such as temperature and dissolved oxygen of each aquarium were monitored at $1 \mathrm{~h}$ interval during the experimental period.

Statistical analysis: All the values were tabulated in Microsoft excel spread sheet and expressed as mean $( \pm \mathrm{SD})$. Filtration rates in different treatments were analyzed by one-way ANOVA followed by Turkey's post hoc test to evaluate statistically significant differences among different treatments. Statistical analyses were performed using SPSS Version 14.0 (SPSS Inc., Chicago, IL).

\section{Results}

The mean shell length, shell width and shell height of experimental mussels were $69.33 \pm 1.05$, $30.82 \pm 0.42$ and $19.27 \pm 0.53 \mathrm{~mm}$ in $\mathrm{T}_{1} ; 66.96 \pm 3.34,30.28 \pm 1.64$ and $19.61 \pm 0.80 \mathrm{~mm}$ in $\mathrm{T}_{2}$; and $67.91 \pm 1.25,30.23 \pm 0.51$ and $19.34 \pm 0.19 \mathrm{~mm}$ in $\mathrm{T}_{3}$ (Table I). The concentration of phytoplankton gradually decreased with the progression of time in each treatment. Among the treatments, density of phytoplankton was remarkably lower in $\mathrm{T}_{2}(\mathrm{pH}$ 8.0) in comparison to other treatments (Fig. 1). The filtration rate was decreasing gradually although the magnitude was not similar in all the treatments. The minimum filtration rate $(58.03 \pm 32.79 \mathrm{ml} / \mathrm{mussel} / \mathrm{h})$ was found in $\mathrm{T}_{3}$ after 1 hour of exposure, whereas the highest filtration rate was obtained in $\mathrm{T}_{2}$ after 2 hours of exposure (Table II).

Mussels stocked in $T_{2}()$ exhibited significantly higher filtration rate $(p<0.05)$ when compared with $\mathrm{T}_{1}()$ and $\mathrm{T}_{3}()$ at all sampling times. However, there was no significant difference in filtration rate $(p>0.05)$ between $\mathrm{T}_{1}$ and $\mathrm{T}_{3}$ (Fig. 2). Temperature was monitored at 1 hour interval during 5 hours exposure time. Water temperature was more or less similar in all 
the treatments examined (Table III). During the experimental period, dissolved oxygen (DO) contents were monitored, that were more or less consistent in all the treatments (Table III).

Table I. Biometric measurements (mean \pm SD) of Lamellidens marginalis in different treatments

\begin{tabular}{cccc}
\hline Treatments & Shell length $(\mathrm{mm})$ & Shell width $(\mathrm{mm})$ & Shell height $(\mathrm{mm})$ \\
\hline $\mathrm{T}_{1}(\mathrm{pH} \mathrm{7.5)}$ & $69.33 \pm 1.05$ & $30.82 \pm 0.42$ & $19.27 \pm 0.53$ \\
$\mathrm{~T}_{2}(\mathrm{pH} 8.0)$ & $66.96 \pm 3.34$ & $30.28 \pm 1.64$ & $19.61 \pm 0.80$ \\
$\mathrm{~T}_{3}(\mathrm{pH} 8.5)$ & $67.91 \pm 1.25$ & $30.23 \pm 0.51$ & $19.34 \pm 0.19$ \\
\hline
\end{tabular}

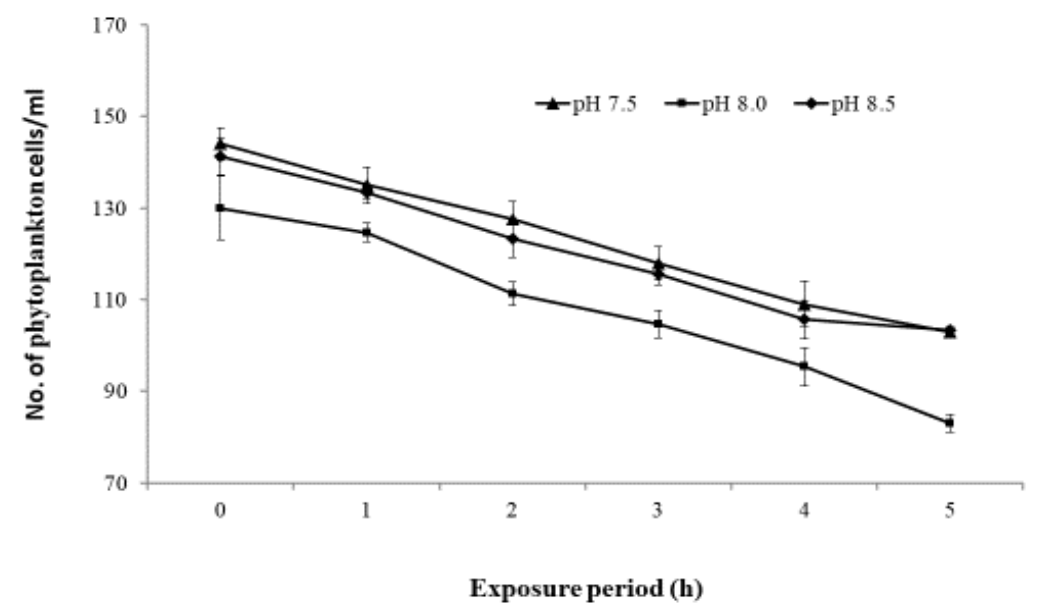

Fig. 1. Changes in density of phytoplankton over time in different treatments.

Table II. Filtration rates of $L$. marginalis at different $\mathrm{pH}$ levels at $1 \mathrm{~h}$ interval for $5 \mathrm{~h}$ exposure time

\begin{tabular}{|c|c|c|c|c|c|}
\hline \multirow[t]{2}{*}{ Treatments } & \multicolumn{5}{|c|}{ Filtration rate $(\mathrm{ml} / \mathrm{mussel} / \mathrm{h})$} \\
\hline & $1 \mathrm{~h}$ & $2 \mathrm{~h}$ & $3 \mathrm{~h}$ & $4 \mathrm{~h}$ & $5 \mathrm{~h}$ \\
\hline $\mathrm{T}_{1}(\mathrm{pH} 7.5)$ & $64.61 \pm 10.25^{\mathrm{a}}$ & $60.23 \pm 34.10^{\mathrm{a}}$ & $\begin{array}{c}66.40 \pm \\
16.17^{\mathrm{a}}\end{array}$ & $69.73 \pm 14.57^{\mathrm{a}}$ & $\begin{array}{c}66.97 \pm \\
3.18^{\mathrm{a}}\end{array}$ \\
\hline $\mathrm{T}_{2}(\mathrm{pH} 8.0)$ & $108.69 \pm 30.59^{b}$ & $110.94 \pm 21.68^{b}$ & $94.58 \pm 12.27^{\mathrm{b}}$ & $94.37 \pm 12.51^{\mathrm{b}}$ & $\begin{array}{c}103.12 \pm \\
5.95^{\mathrm{b}}\end{array}$ \\
\hline $\mathrm{T}_{3}(\mathrm{pH} 8.5)$ & $58.03 \pm 32.79^{\mathrm{ab}}$ & $68.15 \pm 19.32^{\mathrm{ab}}$ & $66.76 \pm 14.74^{\mathrm{a}}$ & $72.76 \pm 2.99^{a}$ & $\begin{array}{c}62.57 \pm \\
5.68^{\mathrm{a}}\end{array}$ \\
\hline
\end{tabular}

Different superscripts $(\mathrm{a}, \mathrm{b}, \mathrm{ab})$ in the same column indicate significant difference $(p<0.05)$ 


\section{Discussion}

In the study, variation in filtration rate of freshwater pearl mussels Lamellidens marginalis at different $\mathrm{pH}$ levels was compared. The $\mathrm{pH}$ is important parameters for mussels growth as they prefer alkaline water due to better growth of their calcareous shell (Areekijseree et al. 2004). The results of the study clearly indicated that mussels exhibited highest filtration at $\mathrm{pH}$ 8.0. Likewise, Loayza-Muro and Elias-Letts (2007) reported that filtration rate was highest at $\mathrm{pH} 8.0$ compared to low water $\mathrm{pH}(4,5,6$ and 7) in freshwater mussel Anodontites trapesialis which is in agreement of the present study. From the study, it can be corroborated that among the different environmental factors, $\mathrm{pH}$ was significantly affected the respiratory mechanism of $L$. marginalis. No mortality was observed during the experimental period at different level of $\mathrm{pH}$ exposure, reflects that freshwater mussels can survive within the $\mathrm{pH}$ ranged from 7.5 to 8.5 , however, they may become stressed between $\mathrm{pH} 7.5$ and 8.5 in relation to water filtration. In contrast to the study, Dimock and Wright (1993) as well as Pynnonen and Huebner (1995) reported the adverse effect of acidic $\mathrm{pH}$ in freshwater mussels which endorsed the selection of $\mathrm{pH}$ ranges in the present study.

The decreased filtration rate at low $\mathrm{pH}$ observed in the study could be explained by temporal and partial closure of shells. Influx of $\mathrm{H}+$ ions which produce tissue irritation and stimulate adductor muscle contraction, resulting in a temporal valve closure. Similarly, this was observed for Anodonta cygnea (Pynnonen and Huebner 1995) and other freshwater unionids under acid stress ( $\mathrm{pH} 4.0$ to 5.0) for extended periods of time. In a related study, Loayza-Muro and Elias-Letts (2007) reported filtration responses of the mussel Anodontites trapesialis to different environmental stressors. The filtration rate was calculated from the clearance of algae, fed to mussels at different temperature, $\mathrm{pH}$ and metal concentrations. The researchers reported that highest filtration rate at $\mathrm{pH} 8$ at $20^{\circ} \mathrm{C}$ and decreased at low temperature and $\mathrm{pH}$ level. In the study, the highest average filtration rate of $L$. marginalis was reported at $\mathrm{pH} 8.0$ and the lowest filtration rate was observed at $\mathrm{pH} 8.5$ which are in agreement with the above study.

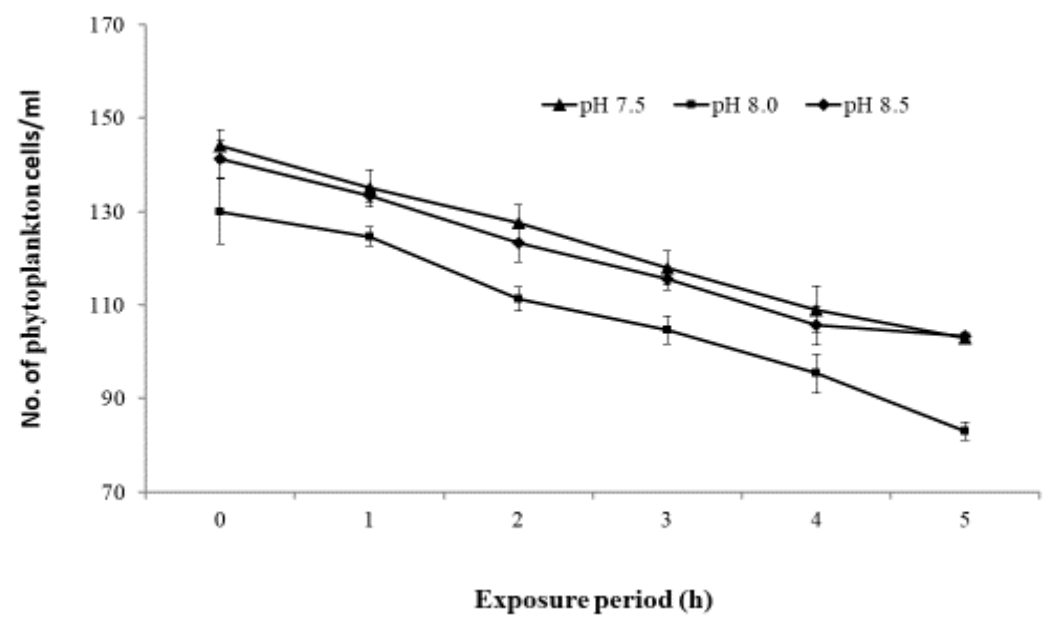

Fig. 2. Filtration rates of Lamellidens marginalis (Mean $\pm \mathrm{SD}$ ) at different $\mathrm{pH}$ conditions in aquaria during 5 hours exposure time. 
EFFECT OF pH ON L. MARGINALIS

Table III. Changes in temperature and dissolved oxygen (DO) level (mean \pm SD) in the study period

\begin{tabular}{|c|c|c|c|c|c|c|c|c|}
\hline \multirow{2}{*}{$\begin{array}{c}\text { Paramete } \\
\mathrm{r}\end{array}$} & \multirow{2}{*}{ Treatments } & \multicolumn{6}{|c|}{ Hours of exposure } & \multirow{2}{*}{ Mean \pm SD } \\
\hline & & 0 & 1 & 2 & 3 & 4 & 5 & \\
\hline \multirow[t]{3}{*}{$\begin{array}{l}\text { Temp. } \\
\left({ }^{\circ} \mathrm{C}\right)\end{array}$} & $\mathrm{T}_{1}(\mathrm{pH} 7.5)$ & $\begin{array}{c}26.73 \pm \\
0.35\end{array}$ & $\begin{array}{c}26.3 \pm \\
0.10\end{array}$ & $\begin{array}{c}26.36 \pm \\
0.05\end{array}$ & $\begin{array}{c}26.46 \pm \\
0.15\end{array}$ & $\begin{array}{c}26.43 \pm \\
0.15\end{array}$ & $\begin{array}{c}26.76 \pm \\
0.25\end{array}$ & $\begin{array}{c}26.50 \pm \\
0.10\end{array}$ \\
\hline & $\mathrm{T}_{2}(\mathrm{pH} 8.0)$ & $\begin{array}{c}26.36 \pm \\
0.72\end{array}$ & $\begin{array}{c}26.56 \pm \\
0.20\end{array}$ & $\begin{array}{c}26.63 \pm \\
0.15\end{array}$ & $\begin{array}{c}26.43 \pm \\
0.15\end{array}$ & $\begin{array}{c}26.7 \pm \\
0.17\end{array}$ & $\begin{array}{c}26.7 \pm \\
0.15\end{array}$ & $\begin{array}{c}26.56 \pm \\
0.22\end{array}$ \\
\hline & $\mathrm{T}_{3}(\mathrm{pH} 8.5)$ & $\begin{array}{c}26.07 \pm \\
0.26\end{array}$ & $\begin{array}{c}26.66 \pm \\
0.15\end{array}$ & $\begin{array}{c}26.53 \pm \\
0.15\end{array}$ & $\begin{array}{c}26.63 \pm \\
0.05\end{array}$ & $\begin{array}{c}26.36 \pm \\
0.05\end{array}$ & $\begin{array}{c}26.63 \pm \\
0.30\end{array}$ & $\begin{array}{c}26.48 \pm \\
0.10\end{array}$ \\
\hline \multirow[t]{3}{*}{$\begin{array}{l}\text { DO } \\
(\mathrm{mg} / \mathrm{L})\end{array}$} & $\mathrm{T}_{1}(\mathrm{pH} 7.5)$ & $\begin{array}{c}5.38 \pm \\
0.22\end{array}$ & $\begin{array}{c}5.42 \pm \\
0.34\end{array}$ & $\begin{array}{c}5.70 \pm \\
0.31\end{array}$ & $\begin{array}{c}5.72 \pm \\
0.1\end{array}$ & $\begin{array}{c}5.58 \pm \\
0.04\end{array}$ & $\begin{array}{c}5.43 \pm \\
0.13\end{array}$ & $\begin{array}{c}5.53 \pm \\
0.12\end{array}$ \\
\hline & $\mathrm{T}_{2}(\mathrm{pH} 8.0)$ & $\begin{array}{c}5.41 \pm \\
0.10\end{array}$ & $\begin{array}{c}5.46 \pm \\
0.27\end{array}$ & $\begin{array}{c}5.80 \pm \\
0.15\end{array}$ & $\begin{array}{c}5.46 \pm \\
0.15\end{array}$ & $\begin{array}{c}5.63 \pm \\
0.06\end{array}$ & $\begin{array}{c}5.52 \pm \\
0.14\end{array}$ & $\begin{array}{c}5.54 \pm \\
0.07\end{array}$ \\
\hline & $\mathrm{T}_{3}(\mathrm{pH} 8.5)$ & $\begin{array}{c}5.64 \pm \\
0.10\end{array}$ & $\begin{array}{c}5.64 \pm \\
0.10\end{array}$ & $\begin{array}{c}5.36 \pm \\
0.32 \\
\end{array}$ & $\begin{array}{c}5.65 \pm \\
0.10\end{array}$ & $\begin{array}{c}5.63 \pm \\
0.12\end{array}$ & $\begin{array}{c}5.44 \pm \\
0.23 \\
\end{array}$ & $\begin{array}{c}5.56 \pm \\
0.09\end{array}$ \\
\hline
\end{tabular}

In the study, $40 \mathrm{ml}$ eutrophicated water having $34.75 \times 10^{5}$ to $36.0 \times 10^{5}$ cells $/ \mathrm{ml}$ of phytoplankton was inoculated in each aquarium to estimate the filtration rate at different $\mathrm{pH}$ levels. Likewise, Loayza-Muro and Elias-Letts (2007) was evaluated the clearance rate of Crypthecodinium sp. suspensions by $A$. trapesialis at a concentration of $2 \times 10^{5} \mathrm{cells} / \mathrm{ml}$. The food source concentration used in the study is similar to that of assess filtration in Mimachlamys asperrima (O'Connor et al. 2000). The filtration rate of L. marginalis ranged from 58 to 110 $\mathrm{ml} / \mathrm{mussel} / \mathrm{h}$, where it was 347 to $567 \mathrm{ml} / \mathrm{mussel} / \mathrm{h}$ in Corbicula sp. (Savina and Pouvreau 2004), 40 to $375 \mathrm{ml} / \mathrm{mussel} / \mathrm{h}$ in Dreissena polymorpha (Horgan and Mills 2011), and 133 to $350 \mathrm{ml} / \mathrm{mussel} / \mathrm{h}$ in Limnoperna fortune (Pestana et al. 2009). Present finding was within the ranges of the above reports when compared. The differences can be possible as the filtration rate may vary considerably among different species of bivalves. Temperature and DO have also considerable effects on the filtration rate of bivalves. Pestana et al. (2009) suggested that the relationship between filtration rates and temperature might depend on the size of the filtered particles in Limnoperna fortunei (Bivalvia, Mytilidae). de Villiers et al. (1989) reported highest filtration rate of infaunal estuarine bivalve Solen cylindraceus with a thermal optimal range of $15-35^{\circ} \mathrm{C}$, declining at higher and lower temperatures. Tang and Riisgard (2017) obtained a high and constant filtration rate of blue mussel (Mytilus edulis) when exposed to oxygen concentrations decreasing from 9 to $2 \mathrm{mg} / 1$ however, at oxygen concentrations below $2 \mathrm{mg} / 1, M$. edulis responded by gradually closing its valves, resulting in a rapid decrease of filtration rate, concurrent with a rapid reduction of respiration rate. In our experiment, we observed more or less constant temperature and DO levels throughout the 5-h period might suggest that these parameters might not affected considerably the filtration rate of $L$. marginalis.

Conclusions: Filtration rate of freshwater pearl mussel L. marginalis exposed to different $\mathrm{pH}$ up to $5 \mathrm{~h}$ was determined to understand the filtration capacity in relation to alkaline $\mathrm{pH}$ level. The filtration rate was decreasing consistently with the progression of exposure time. Mussels stocked at $\mathrm{pH} 8.0$ exhibited significantly higher filtration rate and showed minimum rate when stocked in $\mathrm{pH} 8.5$ after $1 \mathrm{~h}$ of exposure whereas the highest filtration rate was obtained in $\mathrm{pH}$ 8.0 after $2 \mathrm{~h}$ of exposure. The results indicated that $\mathrm{pH}$ has a clear effect on freshwater pearl 
mussel especially at $\mathrm{pH} 8.0$ where the maximum filtration of $L$. marginalis is observed. The study is of importance to provide better environmental conditions for optimum growth of this species. However, the physiological mechanisms involved in the filtration of freshwater mussels at different $\mathrm{pH}$ should be ascertained.

Acknowledgments: The research was supported by the Bangladesh Fisheries Research Institute (Project \# 2018/521/BFRI) under a development project "Conservation, Propagation and Culture of Mussels and Snails in Bangladesh" funded by the Ministry of Fisheries and Livestock, Bangladesh.

\section{Literature Cited}

Areekijseree, M, A. Engkagul, U. Kovitvadhi, A. Thongpan, M. Mingmuang, P. Pakkong, and K. Rungruangsak-Torrissen, 2004. Temperature and $\mathrm{pH}$ characteristics of amylase and proteinase of adult freshwater pearl mussel, Hyriopsis (Hyriopsis) bialatus Simpson 1900. Aquaculture, 234: 575-587.

Coughlan, J., 1969. The estimation of filtering rate from the clearance of suspensions. Mar. Biol. 2: 356-358.

Dame, R., N. Dankers, T. Prins, H. Jongsma, and A. Smaal, 1991. The influence of mussel beds on nutrients in the Western Wadden Sea and Eastern Scheldt Estuaries. Estuaries, 14: 130-138.

Dan, H., M.A. Mazid, and M.G. Hussain, 2001. Freshwater pearl culture, principles and techniques. Bangladesh Fisheries Research Institute, Mymensingh, Bangladesh. 104 p.

de Villiers. C.J., B.R. Allanson and A.N. Hodgson, 1989. The effect of temperature on the filtration rate of Solen cylindraceus (Hanley)(Mollusca: Bivalvia). South Afr. J. Zool., 24: 11-17.

Dimock, R.V., and A.H. Wright, 1993. Sensitivity of juvenile freshwater mussels to hypoxic, thermal and acid stress. J. Elisha Mitchell Sci. Soc., 109(4): 183-192.

Heming, T.A., G.A. Vinogradov, A.K. Klerman, and V.T. Komov, 1988. Acid-base regulation in the freshwater pearl mussel Margaritifera margaritifera: effects of emersion and low water pH. J. Exp. Biol., 137: 501-511.

Horgan, M.J., and E.L. Mills, 2011. Clearance rates and filtering activity of zebra mussel (Dreissena polymorpha): implications for freshwater lakes. Can. J. Fish. Aquat. Sci., 54(2): 249-255.

Jana, B.B., and S. Das, 1997. Potential of freshwater mussel (Lamellidens marginalis) for cadmium clearance in a model system. Ecol. Eng., 8: 179-193.

Kadar, E., J. Salanki, J. Powell, K.N. White, and C.R. McCrohan, 2002. Effect of sub-lethal concentrations of aluminium on the filtration activity of the freshwater mussel Anodonta cygnea L. at neutral pH. Acta Biol. Hung., 53(4): 485-493.

Kunz, J.L., E.L. Brunson, M.C. Barnhart, E.A. Glidewell, N. Wang, and C.G. Ingersoll, 2020. Pulsed flow-through auto-feeding beaker systems for the laboratory culture of juvenile freshwater mussels. Aquaculture, 520:

Loayza-Muro, R., and R. Elias-Letts, 2007. Responses of the mussel Anodontites trapesialis (Unionidae) to environmental stressors: effect of $\mathrm{pH}$, temperature and metals on filtration rate. Environ. Pollut., 149: 209-215.

Mandal, R.N., K. Kumar, U.L. Mphanty, and P.K. Meher, 2007: Estimation of gut contents of freshwater mussel, Lamellidens marginalis. L. Aquac. Res., 38(13): 1364-1369.

Miah, M.I., A.S.M.K Rahman, S.M. Rahmatullah, J.K. Saha, and M.A. Islam, 2000. Culture 
of pearl in freshwater mussels (Lamellidens marginalis Lamarck). Bangladesh J. Fish. Res., 4: $57-61$.

Niogee, S.R., M.A. Khatun, K.F. Tonni, A.K. Barman, M.B. Tanu, S. Sku, and M.J. Uddin, 2019. Ovarian cycle of freshwater pearl mussel, Lamellidens marginalis (Lamarck, 1819) collected from a culture pond in Bangladesh. Asian Fish. Sci., 32: 117-123.

Nobles, T., and Y. Zhang, 2015. Survival, growth and condition of freshwater mussels: effects of municipal wastewater effluent. PLoS ONE, 10(6): e0128488. doi:10.1371/journal.pone. 0128488

O'Connor, W.A., M.P. Heasman, and S.J. O'Connor, 2000. Algal diets for brood stock maintenance of the doughboy scallop Mimachlamys asperrima. Aquac. Res., 31: 627-635.

Patterson, M.A., R.A. Mair, N.L. Eckert, C.M. Gatenby, T. Brady, J.W. Jones, B.R. Simmons, and J.L. Devers, 2018. Freshwater mussel propagation for restoration. Cambridge University Press, pp. 320.

Pestana, D, A. Ostrensky, W.A.P. Boeger, and M.R. Pie, 2009. The effect of temperature and body size on filtration rates of Limnoperna fortunei (Bivalvia, Mytilidae) under laboratory conditions. Braz. Arch. Biol. Technol., 52: 135-144.

Pynnonen, K.S., and J. Huebner, 1995. Effects of episodic low pH exposure on the valve movements of the freshwater bivalve Anodonta cygnea L. Water Res., 29(11): 2579-2582.

Sangsawang, A, U. Kovitvadhi, and S. Kovitvadhi, 2019. The effect of water temperature on the early-life development, growth and survival of the freshwater mussel Hyriopsis bialata. Aquaculture, 510: 311-317.

Savina, M., and S. Pouvreau, 2004. A comparative ecophysiological study of two infaunal filter-feeding bivalves: Paphia rhomboides and Glycymeris glycymeris. Aquaculture, 239: 289-306.

Siddique, M.A., M.A. Khatun, M.M. Rahman, G.U. Ahmed, M. Moniruzzaman, and M.J. Uddin, 2020. Annual gametogenic cycle of the freshwater pearl mussel, Lamellidens marginalis (Lamarck, 1819) collected from a perennial lentic habitat of Bangladesh. Mollus. Res., 40(1): 36-43.

Soto, D., and G. Mena, 1999. Filter feeding by the freshwater mussel, Diplodon chilensis, as a biocontrol of salmon farming eutrophication. Aquaculture, 171: 65-81.

Soucek, D.J., T.S. Schmidt, and D.S. Cherry, 2001. In situ studies with Asian clams (Corbicula fluminea) detect acid mine drainage and nutrient inputs in low-order streams. Can. J. Fish. Aquat. Sci., 58: 602-608.

Tang, B. and H.L. Riisgard, 2017. Relationship between oxygen concentration, respiration and filtration rate in blue mussel Mytilus edulis. Chinese J. Oceanol. Limnol,,36:395-4404.

Uddin, M.J., H.J. Jeung, H.S. Yang, B.K. Kim, S.J. Ju, and K.S. Choi, 2013. Quantitative assessment of reproductive effort of the Manila clam Ruditapes philippinarum in a lagoon on Jeju Island (Korea) using enzyme-linked immunosorbent assay. Invertebr. Reprod. Dev., 57: 316-324. 